\title{
Ethnicity and Public Space in the City: \\ Ethnic Precincts in Sydney
}

\author{
Jock Collins and Patrick Kunz
}

\begin{abstract}
Ethnic precincts demonstrate how cultural diversity shapes public spaces. They are clusters of ethnic entrepreneurs who line the precinct streets selling food, goods or services in areas designated as ethnic precincts by local government officials who fund makeovers of public spaces to display ethnic iconography and symbolism to promote the area based on the 'ethnic' experience. Ethnic precincts are a key site of production and consumption of the ethnic economy, a commodification of place where the symbolic economy of space is constructed on representations of ethnicity and 'immigrantness'. To explore how ethnic diversity shapes public space we present findings of recent fieldwork in four Sydney precincts. We examine the complex relationship between immigrant entrepreneurs, local government and ethnic community representatives in shaping the emergence and development of ethnic precincts and demonstrate how perceptions of the authenticity of ethnic precincts vary according to whether customers are 'co-ethnic', 'co-cultural' or 'others'.
\end{abstract}

\section{Introduction}

Increasing rates of permanent and temporary immigration (Castles and Miller, 2003) mean that immigrant minorities are reshaping the built environment of urban neighborhoods and streetscapes of the cities in their host society where they settle. The increasing importance of cultural landscapes of tourism (Urry, 2002; Selby, 2004) and of the way that cosmopolitan cities generate diversity and excitement (Florida, 2003, p. 227) and tolerance of difference that give cities a creative edge (Florida, 2005, p. 6) have given increasing importance to the issue of the commodification of ethnic diversity in the city. In discussing the 'symbolic economy', Zukin (1995) points to the role of ethnic diversity in shaping place and space, and then relates this to a tendency to commodify cosmopolitan lifestyles and turn them into a vital resource for the prosperity and growth of cities. This involves what MacCannell (1999, 1973) calls a 'reconstructed ethnicity' 
and a 'staged authenticity' or the consumption of signs, symbols, festivals and spectacles used in creating aestheticized spaces of entertainment and pleasure to create a symbolic economy (Zukin, 1995, pp. 3-11).

Ethnic precincts are one example of the spatial dimensions of the commodification of ethnic diversity in cities (Rath ed., 2006). Ethnic precincts are places in the city that combine both private and public spaces and where the cultural and symbolic economy gain prominence shaped by the interaction of producers (ethnic entrepreneurs), consumers and the critical infrastructure (regulators, community leaders, critics, placemarketers) (Zukin, 1995). The private spaces are those of the ethnic and other entrepreneurs that exist in the forms of restaurants, cafes, shops and other businesses that are the main attractor of people to the ethnic precinct. The public spaces are the streets, footpaths, malls, squares, pedestrian thoroughfares and transport nodes outside the private businesses in the ethnic precinct. They have been developed to include ethnic iconography, symbols and design to reflect the ethnicity of the precinct, a public spatial form of the commodification of ethnicity.

Ethnic precincts are thus compelling sites to explore the relationship between ethnic diversity and public space in the city and the contradictions that emerge. This article reflects on recent research conducted in 2004 and 2005 in four ethnic precincts Chinatown, Little Italy, Auburn (Little Turkey) and Cabramatta ('Vietnamatta') - in Sydney, Australia’s largest and most multicultural city (Collins and Castillo, 1998; Burnley, 2001). In each of the ethnic precincts we consulted with five community leaders 
and local government representatives and five ethnic entrepreneurs. We also surveyed 50 consumers (50 per cent female), approaching every third passerby.

The structure of the paper is as follows. The next section reviews the interdisciplinary literature on ethnicity and place in cities. The following one presents an introduction to the four Sydney ethnic precincts that were the sites of the fieldwork reported here. The remainder of the paper contains a section on each ethnic precinct before a brief conclusion of the main themes of this article.

\section{Points of Departure}

As a consequence of immigration, most cities in Australia, and cities in many other western countries, have become cosmopolitan cities that are home to people from a wide range of ethnic backgrounds. In Australia's two largest cities of Sydney (Collins and Castillo, 1998) and Melbourne (Collins et al., 2000), for example, over half of the population today are first- and second-generation immigrants who come from a very wide range of different ethnic backgrounds (Burnley, 2001). In North America, cities such as New York, Los Angeles, Chicago, Toronto, Vancouver and Montreal have very large and diverse immigrant populations, as have European cities such as London and Paris. In these cosmopolitan cities ethnic diversity shapes public space in a number of direct and indirect ways. First, immigrant settlement patterns lead to ethnic concentrations in different suburbs of the city. In some cities ethnic communities are highly concentrated

across the whole city, such as Cubans in Miami (Wilson and Martin, 1982), or highly concentrated in certain areas of the city such as the ethnic Chinese in Richmond 
Vancouver (Hiebert and Ley, 2003)). In cities like Sydney, New York, London and Toronto most residential areas are in fact very culturally-diverse, the home to a large number of first- and second-generation immigrants from diverse ethnic backgrounds rather than one specific ethnic group (Burnley, 2001). The public places and spaces in these cities develop a multicultural character, with different ethnic groups often vying for influence and representation.

Second, when immigrant entrepreneurs cluster together in a street, suburb or area, an ethnic precinct may emerge (Waldinger et al., 1990; Light and Rosenstein, 1995; Collins et al., 1995; Light and Gold, 2000; Rath ed., 2000; Kloosterman and Rath eds, 2003). The emergence of ethnic precincts in the city is a long-established feature of many immigrant cities in North America and Australia, with Chinatowns an almost universal form of this ethnicized place in contemporary western cities (Anderson, 1990, 1991; Zhou, 1992; Kinkead, 1993; Fong, 1994; Fitzgerald, 1997; Lin, 1998). Other ethnic precincts such as Little Italy (Conforti, 1996), 'Little India’ (McEvoy, 2003; Chang, 2000), 'Little Bavaria’ (Frenkel and Walton, 2000), 'Little Sweden' (Schnell, 2003) and 'Finntowns' (Timothy, 2002) have emerged across many continents. A key feature of these ethnic precincts is the provision of ethnic food and ethnic restaurants (Warde, 1997; Warde and Martens, 2000; Gabaccia, 1998), while most ethnic precincts are also sites where ethnic community organisations are located and their activities, including ethnic festivals, are staged.

Ethnic precincts are fundamentally contradictory sites (Collins, 2006). First, there is the problem of the credibility and authenticity of the ethnic precincts, which involves who is 
'authorized' to claim authenticity, how that authenticity is symbolized and what employees and employers in ethnic enterprises have to do to generate that authenticity. Second, how legitimate can a precinct be in the eyes of the co-ethnic community, other locals and tourists if it has been developed by deliberate regulation, planning and government intervention? Third, there is the problem of control and the ways that crime in ethnic precincts threatens the safety of the ethnic tourist experience.

The spatial dimensions of immigrant entrepreneurship are in turn shaped by regimes of regulation from local, provincial and national authorities (Hoffman, Fainstein and Judd (eds.) 2003). These regulators make the urban planning decisions to confer on a part of the city an ethnic character and decide the way that this is represented in the public spaces of streetscapes and pedestrian malls and squares where monuments and other ethnic iconography are installed to demonstrate the ethnic character of that place. This planning process involves consultations with ethnic entrepreneurs and the local ethnic community leaders. In addition to city planners, place marketers, tourist guides and food and culture critics and local ethnic community organisations - what Zukin $(1995,1998)$ calls the critical infrastructure of the symbolic economy - play a role of simultaneously advertising and promoting ethnic precincts and cultural diversity in the city in a way that maximizes the appeal to locals and tourists alike (Halter, 2000; Selby, 2004).

The major symbolic representation of the urban ethnic precinct is ethnicity and ethnic diversity. Yet what constitutes such an 'authentic' ethnic tourism experience within the city? What symbols are appropriate, who decides, and how? There is a fundamental 
contradiction here emerging from the coincidence of outdated ethnocultural stereotypes and tourist iconography in countries of immigration that usually depict a static homogeneity of immigrant or ethnic experience and the dynamic diversity of contemporary life in countries of immigrant origin. As Fainstein, Hoffman, and Judd, (2003, p. 246) put it: "The tension between differentiation and homogeneity makes for a contradiction and conflict in urban tourism regimes.” The problem with the concept of authenticity when applied to the ethnic economy is that it is subjective (Cohen, 1988; MacCannell, 1973). Thus, what constitutes an 'authentic' ethnic or cultural eating or tourist experience could vary according to the different standpoints of those who participate in the daily life of the ethnic precinct. As Meethan (2001, p. 27) has put it, symbols "are multivocal, that is, they have the capacity to carry a range of different, if not ambiguous and contradictory meanings”. Meethan (2001) reminds us that authenticity is a matter of negotiation and ascribed meaning.

One of the critical parts of an ethnic precinct is its outer façade. What constitutes an authentic Chinese/Italian/Vietnamese place and how do you develop it? Bryman (2004, p. 52) refers to the centrality of theming in contemporary consumption places and the contradictions inherent in such theming attempts. Critics of theming often disapprove of the use of symbols of nostalgia for thematic cues. Drawing on faux designs and histories, theming in terms of nostalgic references is often depicted as presenting a sanitized history, one that removes any reference to hardship and conflict in the cause of consumption. The processes by which the public façade of ethnic precincts is developed, 
the authenticity of these ethnic precincts and the contradictions that emerge are explored in the rest of this article by a study of ethnic precincts in Sydney.

\section{Ethnic Precincts in Sydney}

Sydney is one of the most cosmopolitan cities in the world today (Collins and Castillo, 1998; Connell, 2000), with 58 per cent of the population of four million either first- or second-generation immigrants. Sydney’s downtown has a prominent and long-established Chinatown, although most of Sydney's other ethnic precincts are located in the suburbs of southwestern Sydney. Sydney's ethnic precincts include Leichhardt (Little Italy), Campsie (Little Korea), Petersham (Portuguese) and Marrickville (once Greek, now Vietnamese) and Ashfield (Chinese) in Sydney's inner-southwestern suburban ring. In the middle-southwestern suburban ring, ethnic precincts include Auburn (Turkish quarter), Lakemba and Punchbowl ('Middle Eastern’) and Bankstown (Asian and Middle Eastern). Cabramatta, in the Fairfield municipality, is even further from the city center and has become an Asiatown (Burnley, 2001). For the sake of brevity, only the ethnic precincts of Chinatown, Little Italy, Auburn and Cabramatta will be explored in any detail in this article.

Areas become ethnic precincts because of the ethnicity of the entrepreneurs who own the businesses in the area and/or through patterns of immigrant settlement. In long established ethnic precincts such as Little Italy and Chinatown there is a history of Italian and Chinese immigrant settlement and of immigrant entrepreneurs remaining long after subsequent waves of Italian and Chinese immigrants moved out to other parts of Sydney. 
In newly emerging ethnic precincts such as Auburn and Cabramatta the presence of large numbers of Turkish and Vietnamese immigrants and entrepreneurs is also a critical factor to their emergence. However, the presence of immigrant settlers and entrepreneurs is a necessary but not a sufficient condition for the emergence of ethnic precincts: it is also necessary for regulatory authorities to promote the area as an ethnic precinct and to further develop and encourage an 'ethnic feel' to the area by promoting ethnic signage in the public spaces of the precinct and holding ethnic festivals there.

The focus in this article is on the public space of the ethnic precinct, that is, the footpaths, pedestrian malls, public squares and other spaces at streetscape level. In addition to the infrastructure developed in these ethnic precincts - the signage, symbols and motifs of ethnic culture - it is the ethnic enterprises at street level that give the area its ethnic character. In Chinatown, Little Italy, Auburn and Cabramatta the common feature is the overwhelming concentration of ethnic entrepreneurs who own and operate enterprises at this street level, predominantly involved in food and retail activities. Above this level ethnic entrepreneurs still predominate, but are more likely to be professionals providing health, legal and commercial services. This in turn attracts 'co-ethnic' customers to the precinct, adding to the ethnic character of the passing parade of the street crowd. 
Table 1. Concentration of Ethnic Entrepreneurs in Street Level Business Enterprises in each Ethnic Precinct

\begin{tabular}{|l|l|l|}
\hline Precinct & $\begin{array}{l}\text { Ethnicity of } \\
\text { Entrepreneurs }\end{array}$ & $\begin{array}{l}\text { Per cent of all } \\
\text { Entrepreneurs in the } \\
\text { Precinct }\end{array}$ \\
\hline Chinatown & Chinese & 89 \\
\hline & Australian & 5 \\
\hline Little Italy & Italian & 91 \\
\hline & Australian & 4 \\
\hline Little Turkey & Turkish & 78 \\
\hline & Chinese & 14 \\
\hline Vietnamatta & Vietnamese & 86 \\
\hline & Chinese & 10 \\
\hline
\end{tabular}

Source: Fieldwork 2004-05

\section{Methodology}

A mix of quantitative and qualitative methodologies was employed in designing the fieldwork for this investigation of Sydney's ethnic precincts. The research instruments involved the fieldwork in the four case studies of Sydney's ethnic precincts were in-depth interviews with five immigrant entrepreneurs (producers) and five members of the critical infrastructure in each ethnic precinct and a survey of consumers fifty customers in each precinct. In addition, a door-to-door visit of all the enterprises in each ethnic precinct was used to determine the ethnicity of the owners of the precinct's enterprises. By member of the critical infrastructure we meant that the person was involved in the cultural tourism industry as a representative of a body, institution, organisation or enterprise and who influenced, directly or indirectly, the ethnic precinct as a whole or the goods or services available in the ethnic precinct. By producer we mean an ethnic entrepreneur who was owner-manager of at least one urban tourism industry organisation or enterprise that was 
located within the boundaries of the ethnic precinct and who supplied, directly or indirectly, products or services demanded by cultural urban tourists,.

Five immigrant entrepreneurs (producers) and five members of the critical infrastructure were selected for interview in each ethnic precinct using a two stage purposive sample. In each ethnic precinct we contacted 25 producers and 10 members of the critical infrastructure, drawn from a number of sources, including networks, websites and local directories. These were sent e-mail invitations to participate in the research project. This was followed by a telephone call eight weeks later. This netted fifty-four producers and thirty five critical infrastructure members who were willing to take part in the research. From these, the sample was selected, with all the female respondents included because fewer females responded positively to our call. Consumers were interviewed in the streets of the ethnic precinct. They were selected by way of purposive random sampling. A random number of 1 to 5 was selected prior to going into the field and the nth passing consumer was approached for an interview. This led to a survey of 50 consumers in each ethnic precinct (See Tables 2, 3, 4 and 5).

\section{Chinatown}

Sydney's Chinatown has existed in the downtown area of the city since the 1860s. In the 1940s Chinatown moved to Campbell and Dixon Streets where it is still located today (Collins and Castillo, 1998, pp. 278-289; Fitzgerald, 1997). Chinatown is a residential and commercial center of Chinese settlement in Sydney. Today, as Table 1 shows, 89 per cent of the enterprises in the Chinatown precinct are owned by Chinese entrepreneurs 
while an increasing number of ethnic Chinese are living in or nearby the Chinatown precinct in high-rise apartment blocks that have been developed in the past decade.

Chinatown has been promoted as a precinct through a series of attempts by state and local government and the Chinese community to put the ethnic Chinese mark more firmly on this city space. The Sydney City Council has played a key role in the planning and funding of a number of makeovers of Chinatown over the years, including: the redevelopment of Dixon Street in 1972 by introducing portico, lanterns, and trash bins with 'traditional' Chinese symbols; development of a pedestrian thoroughfare in Dixon Street; the erection of Chinese dragons and the planting of Chinese trees along the streetscape in the 1980s; and linking Chinatown to the new Darling Harbour development via a Chinese Gardens in the 1990s (Fitzgerald, 1997). Chinatown is also the site where all major festivals on the Chinese calendar are celebrated, including the largest Chinese New Year celebrations held outside China. It is interesting to note that the poster advertising the 2006 Chinese New Year Festival featured, on the advice of the Chinese consultative committee, not dragons, lions, arches or Chinese characters - as might be expected by westerners - but rather two cartoon doll-like figures of contemporary Chinese popular culture, once again highlighting the contradictory meanings of the symbols of ethnicity.

The Sydney City Council is currently planning for a new makeover of the public spaces and areas of Chinatown in consultation with ethnic Chinese community leaders and entrepreneurs. But is Chinatown an authentic representation of Chinese-ness? Anderson 
(1990, p. 150) argues that Sydney's Chinatown has been revitalized in ways that reflect white Australia's image of Chinese-ness: "Making the area more 'Chinese'...[meant] making the area appear more consistent with the architectural motifs and symbols of ancient China." In other words, attempts by the Sydney City Council to 'create' a Chinatown in an image that would attract tourists have resulted in façades, monuments and facelifts reflecting stereotypical images of a homogeneous 'Chineseness' that exists only in the 'white gaze', an argument also made about Chinatowns in New York (Lin, 1998, p. 173) and Vancouver (Anderson, 1991). But consultation with the Chinese community in Sydney is selective: there are over 100 different ethnic Chinese community organizations in Sydney.

An interesting anecdote that emerged during our fieldwork highlights some of these issues. One of the previous attempts at Chinese theming of the Chinatown precinct relates to the erection of a sculpture titled Golden Water Mouth at footpath level which was designed by artist Lin Li, using a 200-year-old dead gum tree lined in gold on its top half, out of which water flows and trickles down. This is clearly designed to reflect the early Chinese history of settlement during the Australian Gold Rush of the 1850s: as the plaque on the sculpture states, it "celebrates contemporary life and the historic character of Chinatown. Australian and Chinese cultures are signaled in the combination of materials creating a Ying-yang harmony using traditional Chinese principles of Feng Shui”. However the chair of the Chinese consultative committee established by the Sydney City Council argues that a dead tree with water (money) flowing out is bad Feng Shui. Another Chinese informant who runs walking tours of Chinatown for tourists disagrees, 
suggesting that the sculpture is authentically Chinese, confirming Meethan's (2001, p. 27) argument about the multivocal, ambiguous and contradictory meanings that symbols of ethnicity carry.

In order to explore these contradictory meanings of reconstructing Chinese ethnicity in Chinatown's public spaces we conducted interviews with passers-by - consumers and customers who were locals or tourists - on the streets of Chinatown. We found significant differences in terms of what aspects of Chinatown conveyed a sense of authenticity between those visitors/customers who were co-ethnics (that is, ethnic Chinese) compared to those who were non-Chinese Asians (who we call co-cultural) and the rest, that is, other non-Asian immigrant minorities and the majority Anglo-Celtic community (who we call others). Co-ethnic customers were generally critical of the streetscape revitalization efforts, which they considered to be kitschy [not a word that they used], and, at times, inauthentic and offensive. As one Chinese customer surveyed put it, "It's [highly visible Chinese iconography in the precinct] like fully eww [sic]" (ID CT.C.38). On the other hand, co-cultural consumers were largely indifferent to the ethnic theming and façade of the precinct. In contrast, other consumers were strongly attracted to Chinatown because of the highly visible ethnic façade and feel of the precinct itself: the lions, arches and lanterns and the Chinese characters on the restaurant façades were considered tasteful and authentic, although they preferred that the signage in the precinct also be in English. They were also attracted by the large number of apparently Chinese (co-ethnic) customers in the public thoroughfares of the precinct. As a corollary, we also found that the co-ethnic consumers often accused these other customers of gawking at them as if they, like the 
other elements of the Chinatown façade, were on display as one of the 'exotic sights' of Chinatown. This angered them a great deal. For example, a Chinese female surveyed said: "Well, you have these people [other consumers] looking and looking at you [it]... is so rude (ID CT.C.40). Another female ethnic Chinese consumer put it another way: “I think they [other consumers] come here [Chinatown] with expectations to see all things Chinese, that includes us [co-ethnic individuals]” (ID CT.C.44). This evokes images of Lin’s (1998, pp. 174-76) account of how middle-class New Yorkers in the 1880s liked “to go slumming in Chinatown”, riding in "rubbernecker vehicles” (also known as 'gape wagons'), with the term rubbernecker (for a gawking tourist) entering into American parlance during this era. The other consumers, in response, steadfastly refuted the corresponding claims of gawking and countered that the co-ethnic consumers were being overly sensitive.

The Chinese entrepreneurs we consulted also reported a difference between their coethnic, co-cultural and other customers. Co-ethnic consumers were deemed excessively price sensitive. As one Chinese entrepreneur who ran a premium gift shop put it, "It's bloody nauseating sometimes, neh, neh, neh [sic], [co-ethnic customers are] like kids, big kids, over any increase [in prices]. They've [co-ethnic customers] got a lot of cheek, really...it's only because I'm Chinese. They reckon “Ah, he's a Chinese, I'm Chinese, I can get a discount” (ID CT.P.2a). Co-cultural consumers in each precinct were also respectively seen as price sensitive, though to a lesser degree than co-ethnic consumers; while other consumers were consistently regarded the least price sensitive of all consumers and were prepared to pay premium prices for products and/or services because 
of their 'uniqueness'. As a Chinese male owner-manage of a supermarket put it "we have this tea [Chinese tea and]...they [other consumers] come in [and say] 'Wow, special tea'...I charge...double sometimes, and they're happy to pay" (IC CT.P.5a). The Chinese entrepreneurs occasionally found other consumers to be rude and/or condescending, or arrogant, but were prepared to put up with this because of the increased income potential of other consumer patronage.

\section{Little Italy}

Italian immigrants and Italian entrepreneurs have a strong history of settlement in Leichhardt, which is an inner-western suburb 6 kilometers from the central business district (CBD) (Collins, 1992). Italian entrepreneurs in Leichhardt date from 1885 when fishmonger Angelo Pomabello and the fruiterers Bongiorno brothers opened a fruit shop on Parramatta Road (Collins and Castillo, 1998, p. 158). Leichhardt was the center of post-war Italian immigrant settlement in the 1950s and 1960s, but moved to middle- and outer-ring suburbs in later decades. By 2001 there were only 5 per cent of Leichhardt's population who were born in Italy. But the Italian entrepreneurial presence had been retained and expanded. Today Leichhardt, especially along Norton Street, with its outdoor cafes, restaurants and delicatessens reminiscent of Roman street scenes, has maintained its definite Italian feel. Burnley (2001, p. 171) lists 325 Italian-owned businesses in Leichhardt and neighboring Five Dock, including 33 restaurants, 18 cafes, 13 butchers and 11 pasticceria). As Table 1 shows, 91 per cent of the street-level enterprises in the Little Italy precinct are owned by first and second generation Italians. 
The Leichhardt Municipal Council has been critical in the development of the Italian façade in the public places of Little Italy, providing funds for a series of 'facial makeovers' of the area. This involved developing wider footpaths for outside tables to produce the feel of the 'alfresco' Italian eating experience - permitted after a change in food regulations by the NSW state government in the mid 1980s - and encouraging Italian entrepreneurs to redevelop their restaurants to add upstairs balconies. Leichhardt Council approved and promoted the development of the Italian Forum, financed by the late Italian immigrant millionaire, Franco Belgiorno-Nettis, comprising of a large residential and commercial development that recreates the Italian village feel complete with four floors of residences with Juliet balconies overlooking and encircling a large piazza where the tables of Italian restaurants had room to spread out under the stars. The Forum even featured a clock tower, wandering Italian musicians and a central fountain. The Council also sponsors the annual Norton Street Festival when the street is closed and lavishly decorated and cars are replaced by food and market stalls decorated in the green, red and white Italian colors, attracting over 100,000 people a year (Collins and Castillo, 1998, p. 169).

Despite the population loss, Little Italy is more vibrant and more 'Italian' in look, feel, smell and taste than ever, especially along Norton Street. As with the Chinatown precinct, other visitors to Little Italy were attracted to it because of the promise of the authentic Italian experience: the noise and bustle of Italian families walking arm-in-arm along the footpaths, gelatos in hand; the smells of Italian restaurants owned by Italian entrepreneurs serving "authentic" Italian food; drinking cappuccinos at Italian cafe tables on the 
footpath watching the passing parade to the noise and fumes of the hot cars driven be preening, macho Italian young men revving up and down Norton Street. The co-ethnic visitors to Little Italy go there regularly, often driving many kilometers from their place of residence to visit Italian accountants, legal and medical professionals, to meet relatives and friends over a meal and an espresso. They celebrate the rise or fall of the Azzuri with noise and emotion along Norton Street, where the streets were closed to traffic during the 2006 World Cup final, but are not overly attracted by its Italianate façade. They did not report concerns on 'gawking' expressed by co-ethnics in Chinatown.

\section{Vietnamatta}

Cabramatta is a suburban 'Asia town' in Sydney's western suburbs 45 kilometers from the city center. Many Vietnamese residents arrived as refugees from the Vietnam War and had been ethnic Chinese business owners or supporters of the south during the War. They moved to the low-rent residential properties in the Cabramatta area from the local Migrant Hostel that provided settlement services and accommodation for new humanitarian arrivals (Vivianni, 1984). The Vietnamese-born, who comprise 32 per cent of Cabramatta's population, are one of the largest of these immigrant groups, which led to the unofficial and racialised name of Vietnamatta for the Cabramatta area by critics of Asian immigration in the 1980s (Collins, 1991, pp. 66-69).

Along John Street, which runs along the western side of Cabramatta Railway Station, a vibrant ethnic precinct has emerged with over 820 ethnic businesses and institutions (Burnley, 2001, p. 252). The owners of these businesses were Vietnamese (particularly 
ethnic Chinese Vietnamese), other Chinese, Laotians, Cambodians and residual Italians, Croatians and Serbs. Today, as Table 1 shows, 86 per cent of the enterprises in the Cabramatta precinct are Vietnamese-born immigrants, while another 10 per cent are Chinese-born immigrants.

As in the case of Chinatown and Little Italy, there has been an attempt by local and state policy makers, the regulators (Hoffman, Fainstein and Judd (eds.) 2003), to redevelop the Cabramatta shopping precinct to attract more customers and visitors from outside the area. In the early 1980s, the Cabramatta Chamber of Commerce - which at that time had no Vietnamese entrepreneurs on it - received a grant of AU\$20,000 from the Fairfield City Council to develop a plaza area along John Street. In the late 1980s, another campaign, 'The Start-Up for Cabramatta Campaign', was introduced with a brief to "change unfavorable images, to promote the acceptance of the Indo-Chinese community and foster multicultural activities such as the Fan Festival, the Dragon Boat Race, an International Cabaret and 'good eating'” (Burnley, 2001, p. 248).

The unfavorable image was due to Cabramatta's growing reputation as an unsafe area in 1988-89 there were 15 murders in the area - and one of Sydney's heroin centers (Burnley, 2001, p. 248). This is the contradiction between ethnic precincts as places to see and experience the exotic on the one hand and the fear for safety that comes with a criminalization of immigrant minorities on the other (Collins, 2006; Poynting et al., 2004). Urban planning for the Cabramatta precinct thus includes developing the ethnic façade of public places in the area while at the same time planning for increased policing 
and surveillance. In 1991 a new Pailau Chinese gateway to Cabramatta’s Freedom Plaza was opened and nine bronze and stone sculptures erected, including two guarding lion sculptures (Burnley, 2001, p. 250). At the same time the NSW State government responded by increasing policing in the area, including police foot-patrols, and the installing CCTV cameras in the main public thoroughfares of the precinct.

Unlike Chinatown and Little Italy, co-ethnic customers in Vietnamatta were more likely to be local residents, although many Vietnamese also travel from other parts of western Sydney to the precinct to eat and shop at businesses owned by Vietnamese entrepreneurs and to socialize and use services provided by Vietnamese immigrant professionals. Like the Chinatown experience, co-ethnics in Vietnamatta reported resentment at the gawking by other customers in the precinct and were not really attracted by the ethnic make-over of the precinct which they often thought 'kitschy'. Co-cultural customers in the precinct were largely indifferent to the ethnic façade of the precinct and were attracted because they lived in the area and/or wanted to make use of the Vietnamese-owned enterprises there and the authentic goods and services that they provided. The other customers were attracted to the precinct by the place-marketing promise of 'a day in Asia', the ethnic iconography of the public spaces in the area and the exotic food and shopping available there. They were not too concerned who owned the businesses, as long as they looked, smelt and felt authentic.

The Vietnamese entrepreneurs we consulted complained at not being consulted adequately by the local council in makeovers of the area but, paradoxically, argued that 
they were too busy to spend time away from the business for such consultations. They were more concerned about solving issues of adequate parking in the area and about crime than they were about the need for more investment in 'Asian' iconography in the public spaces of the precinct. None belonged to ethnic or local entrepreneur associations and were more likely to view their co-ethnic entrepreneurs in Cabramatta as competitors than co-operators. The Vietnamese entrepreneurs thought that co-ethnic and co-cultural customers were too price-sensitive while other consumers were more likely to happily pay more for their meals or goods.

As in the other ethnic precincts, the local government authorities promote ethnicity in Cabramatta, and the broader Fairfield City of which it is a part. The Fairfield City Council also invests funds in the place-marketing of the area. Given the ethnic diversity of the Cabramatta and Fairfield population, Cabramatta is promoted by local government authorities as a multicultural precinct rather than a Vietnamese precinct. A glossy brochure targeting visitors to the city and invites tourists thus: "Cabramatta is a day trip to Asia... Here, an hour from the center of Sydney, is an explosion of Asian color - a bustling marketplace offering all the ingredients for a banquet for the senses”. But unlike Chinatown or Little Italy, local authorities have not promoted an official title for the precinct. Vietnamatta has, by default, been the name most commonly used in public and private discourses. Local expert guides accompany visitors on a walk through Cabramatta, helping build an appreciation for the various types of Asian products sold there. More recently the Fairfield City Council launched a 'multicultural driving tour' with a CD and map directing tourists to the ethnic sites and features of Cabramatta. 
Eleven of the fifteen sites pictured are churches, temples, monasteries and a mosque, highlighting the significance of the impact of ethnic communities in shaping the built environment in general and the role of religious buildings in particular in imprinting ethnic diversity on the public spaces of multicultural suburbs like Cabramatta in particular. Cabramatta also is the site of a number of ethnic festivals related to the Chinese, Vietnamese and other ethnic calendars, with the local authorities playing a prominent role in co-ordinating and promoting these festivals in consultation with local ethnic community organisations.

\section{Little Turkey}

Auburn is 20 kilometers to the west of the CBD on the same western railway line that runs through Cabramatta. Up until the 1970s Auburn was a white working-class suburb of predominantly Australian-born or Anglo-Celtic immigrants. In the past three decades that is, much later than the other precincts - immigrant minorities began to move into the area. It has thus escaped the attention of those interested in ethnic entrepreneur research. Like Cabramatta, Auburn is an ethnoburb with a multicultural population. The Turkishborn compromise only 7 per cent of Auburn's population, but as Table 1 shows, 78 per cent of the enterprises in the Auburn precinct are Turkish-born immigrants, while another 14 per cent are Chinese-born immigrants. Auburn is different from the previous three ethnic precincts in that it is a newly emerging precinct and, like Cabramatta, has not been formally marketed or promoted as 'Little Turkey'. The Auburn Council does promote multicultural festivals and has contributed to some ethnic landscaping of the public spaces in Auburn, though in a much more limited sense than the other ethnic precincts. 
As in the other ethnic precincts discussed in this article, the other consumers or visitors to Auburn were most responsive to the proposal for the more formal development of a Little Turkey precinct in the area, while co-ethnics were more ambivalent and complained that the Turkish community has not been sufficiently consulted about the development of the ethnic precinct. Indeed, co-ethnic consumers in Little Turkey praised local council's streetscape revitalization efforts and organizing of festivals precisely because it did not over-promote a highly visible Turkish feel to the wider ethnic precinct. Turkish and other ethnic entrepreneurs in Auburn were more concerned about issues of crime and parking in the precinct. They mentioned young black African males congregating in groups of five to ten along Auburn Road, particularly at night, criticizing both local council and local police for allowing the problem to develop unchecked. Local council refused to place 'no loitering' signs around the ethnic precinct, and local police rarely intervened, directly, to force the groups to move on. Relations between these Turkish entrepreneurs were more competitive than co-operative.

\section{Conclusions}

This paper has investigated the way that ethnicity shapes public spaces in four ethnic precincts in Sydney, two long established (Chinatown and Little Italy) and two emerging Vietnamatta and Little Turkey). It demonstrates the critical role of immigrant entrepreneurs (Kloosterman and Rath eds, 2003) in the emergence of the ethnic economy (Light and Gold, 2000) in general and ethnic precincts (Rath ed., 2006) in particular in the cosmopolitan city. In each precinct the immigrant population was very diverse - they 
were multicultural suburbs - but the business enterprises were dominated by the immigrant groups who comprised around 80 per cent or more of all entrepreneurs in the precinct, even though this ethnic group, with the exception of Cabramatta, comprised less than 10 per cent of the population.

Zukin (1995) stressed the importance of the interaction of producers (ethnic entrepreneurs), consumers, and the critical infrastructure (regulators, community leaders, critics, place-marketers) in the emergence of the cultural and symbolic economy. We have demonstrated how this interaction is critical to an understanding of the emergence of ethnic precincts in Sydney, and explored the inherent contradictions, though we have utilised a narrower interpretation of the critical infrastructure than Zukin envisages with our focus on regulators and ethnic community leaders. More research is needed to investigate the role of cultural critics and place marketers in developing knowledge of and a taste for, literally and figuratively, minority ethnic places in the minds of the majority of other ethnic groups in the city.

In the earlier sections of this article we noted in the international literature that perceptions of the authenticity of such attempts to reconstruct ethnicity (MacCannell, 1999, 1973) and ethnic theming were subjective, multivocal and sometimes contradictory, particularly in relation to Chinatown (Anderson, 1990, 1991), highlighting the contradiction of authenticity in ethnic precincts (Collins, 2006). This was confirmed by the surveys of consumers not only in Chinatown but in the other precincts as well where we found very different consumer responses to, and attitudes about, the 
commodification of ethnicity in the ethnic precinct depending on the consumer's ethnicity, a point not sufficiently appreciated by Zukin (1995). In this paper we have attempted to sketch the different ways co-ethnic, co-cultural and other consumers view ethnic authenticity in the ethnic precinct. Put simply, it is the other consumers who are most attracted to the fabrication of the ethnic precinct, though they requested dual language signage to guide them through the precinct. Co-ethnic customers were generally critical of the streetscape revitalization efforts that were thought to be kitschy, inauthentic and offensive, highlighting the contradiction of the legitimacy of ethnic precinct (Collins, 2006). Co-ethnic consumers often accused other consumers of gawking, a central contradiction of the ethnic precinct where the change of experiencing the 'exotic Other' is what is marketed. But we are also aware that these constructs of consumer difference are not in themselves homogenous. As demonstrated by the anecdote about the Golden Water Mouth sculpture in Chinatown, not all co-ethnics agree in this regard. Similarly, the 'cocultural' and 'other' consumer constructs clearly need more probing as they incorporate such a broad range of ethnic backgrounds and social classes and do not distinguish between tourists (national and international) and locals, with further research needed to unpack these groupings.

In this article we drew on responses from only five immigrant entrepreneurs in each precinct, so that results about their role in the development of the public spaces of ethnic precincts are only suggestive and require further investigation. However, even such a small sample suggests that co-ethnic entrepreneurs in each precinct were more often in conflict and competition with each other than they were a united force, rarely 
communicating with one other and rarely finding time to consult with local authorities about the makeover of the public spaces of the precinct. These ethnic entrepreneurs were more concerned about problems of crime and safety (Collins, 2006) and parking in the precinct than on the development of an ethnic streetscape. The ethnic entrepreneurs also distinguished between different groups of customers: they saw co-ethnic customers as too price sensitive and other consumers as being sometimes rude, condescending and arrogant.

Local and provincial government authorities or regulators (Hoffman, Fainstein and Judd (eds.) 2003) play a critical role in the emergence and development of the ethnic feel and look of the public spaces of each ethnic precinct: in all cases they planned for and funded ethnic makeovers of public spaces in the precinct in consultation more with ethnic community organisations than ethnic entrepreneurs who were often too busy to take part in consultations. The streets of the ethnic precincts were also the sites of a number of annual ethnic festivals, adding another dimension of ethnic reputation of the precinct. However, their urban planning sometimes resulted in inauthentic ethnic makeovers which often lacked legitimacy in the eyes of ethnic community organisations and ethnic entrepreneurs and also needed to respond to issues of crime and safety in the ethnic precinct. 


\section{Bibliography}

Anderson, K. J. 1990, 'Chinatown re-oriented: a critical analysis of recent redevelopment schemes in a Melbourne and Sydney enclave,' Australian Geographical Studies, vol. 28, pp. 131-154.

Anderson, K. J. 1991, Vancouver's Chinatown: racial discourse in Canada, 1875-1980, McGill-Queens University Press, Montreal.

Bryman, A. 2004, The Disneyization of Society, Sage, London.

Burnley, Ian. 2001, The Impact of Immigration on Australia: A Demographic Approach, Oxford University Press, South Melbourne.

Castles, S. \& Miller, M. J. 2003, The Age of Migration, 2nd ed. Macmillan, London.

Chang, T. C. 2000 'Singapore's Little India: A tourist attraction as a contested landscape’, Urban Studies, vol.38, no.2, pp. 343-368.

Cohen, E. 1988, 'Authenticity and commoditization in tourism', Annals of Tourism Research, vol.15, no.3, pp. 371-386.

Collins, J. 1991, Migrant Hands in a Distant Land: Australia's post-war immigration, Pluto Press, Sydney.

Collins, J. 1992, 'Cappuccino Capitalism: Italian immigrants and Australian business’ in S. Castles, C. Alcorso, G. Rando \& E. Vasta (eds), Australia's Italians: Culture and community in a changing society, Allen and Unwin, Sydney,pp. 73-84.

Collins, J. 2006, 'Ethnic Precincts as Contradictory Tourist Spaces’ in J. Rath (ed.) Tourism, Ethnic Diversity and the City, Routledge, London, pp. 52-67.

Collins, J., Gibson, K., Alcorso, C., Tait D., \& Castles, S. 1995, A Shop Full of Dreams: Ethnic Small Business in Australia, Pluto Press, Sydney.

Collins, J. \& Castillo, A. 1998 Cosmopolitan Sydney: Exploring the world in one city, Pluto Press, Sydney.

Collins, J., Noble, G., Poynting, S. \& Tabar, P. 2000 Kebabs, Kids, Cops and Crime: Youth, Ethnicity and Crime, Pluto Press, Sydney.

Conforti, J. M. 1996, 'Ghettos as tourism attractions', Annals of Tourism Research, vol. 23, no.4, pp. 830-842.

Connell, J. (ed.). 2000, Sydney: The Emergence Of A World City, Oxford University Press, South Melbourne.

Fainstein, S.S., Hoffman, L.M. \& Judd, D.R. 2003, 'Making theoretical sense of tourism', in Hoffman, L.M. Fainstein, S.S and Judd, D.R. (eds.). Cities and Visitors:

regulating people, markets, and city space, Blackwell, Oxford, pp. 239-253.

Fitzgerald, S. 1997, Red Tape, Gold Scissors, State Library of NSW Press, Sydney.

Florida, R. L. 2003, The Rise of The Creative Class, Pluto Press, Melbourne.

Florida, R. L. 2005, Cities and the Creative Class, Routledge, New York.

Fong, T. P. 1994, The First Suburban Chinatown: The Remaking Of Monterey Park, California, Temple University Press, Philadelphia.

Frenkel, S. \& Walton, J. 2000, 'Bavarian Leavenworth and the symbolic economy of a theme town', The Geographical Review, vol.90, no.4, pp.559-581.

Halter, M. 2000, Shopping for Identity: The Marketing of Ethnicity, Schocken Books, New York. 
Hiebert, D. \& Ley, D. 2003, 'Characteristics of Immigrant Transnationalism in Vancouver', Research on Immigration and Integration in the Metropolis Working Paper Series, 03-15, October 2003.

Kinkead, G. 1993, Chinatown: a portrait of a closed society, Harper Perennial, New York.

Kloosterman, R. \& Rath, J. (eds). 2003, Immigrant Entrepreneurs: venturing abroad in the age of globalization, Berg, Oxford.

Hoffman, L.M., Fainstein, S.S \& Judd, D.R. (eds.), 2003, Cities and Visitors: regulating people, markets, and city space, Blackwell, Oxford.

Light, I. \& Gold, S. J. 2000, Ethnic Economies, Academic Press, San Deigo.

Lin, Jan. 1998, Reconstructing Chinatown: Ethnic enclave, global change, University of Minnesota Press, Minneapolis.

Light, I. \& Rosenstein, C. 1995, Race, Ethnicity and Entrepreneurship in Urban America. Aidine de Gruyter, New York.

MacCannell, D. 1973, 'Staged authenticity: arrangements of social space in tourist settings', American Sociological Review, vol. 79, pp. 589-603.

MacCannell, D. [1976] 1999, The Tourist, Schocken Books New York.

McEvoy, D. \& Barrett, G.A. 2006, ‘The evolution of Manchester's 'curry mile': From suburban shopping street to ethnic destination', in Kaplan, D. \& Li, W. (eds)

Landscapes of the Ethnic Economy, Rowman and Littlefield, Lanham, pp. 193-207.

Meethan, K. 2001, Tourism in Global Society: place, culture, consumption, Palgrave, New York.

Poynting, S., Noble, G., Tabar, P., \& Collins, J. 2004, Bin Laden in the Suburbs: The criminalisation of the Arabic 'Other', Federation Press, Sydney.

Rath, J. (ed.). 2000, Immigrant Business: the economic, political and social environment, Macmillan/St Martin’s Press, Basingstoke/New York.

Rath, J. (ed.). 2006, Tourism, Ethnic Diversity and the City, Routledge, London.

Schnell, S. M. 2003. 'The ambiguities of authenticity in Little Sweden, USA', Journal of Cultural Geography, vol. 20, no. 2, pp.43-68.

Selby, M. 2004, Understanding Urban Tourism: Image, Culture \& Experience, I. B. Tauris, New York.

Timothy, D. 2002, 'Tourism and the growth of ethnic islands', in C. M. Hall and A. M. Williams (eds.), Tourism and Migration: New Relationships Between Production And Consumption, Kluwer Academic Publishers, Dordrecht, pp. 135-151.

Urry, John. 2002, The Tourist Gaze, Sage, London.

Viviani, N. 1984, The Long Journey: Vietnamese Migration and Settlement in Australia, Melbourne University Press, Carlton.

Waldinger, R., Aldrich,H., Ward, R. \& Associates, 1990, Ethnic Entrepreneurs - Immigrant Business in Industrial Societies, Sage, London.

Warde, A. 1997, Consumption, Food and Taste, Sage, London.

Warde, A. and Martens, L. 2000, Eating Out: Social Differentiation, Consumption and Pleasure, Cambridge University Press, Cambridge.

Wilson, K. \& Martin, W. A., 1982, 'Ethnic Enclaves: A comparison of the Cuban and Black Economies in Miami', American Journal of Sociology, vol. 88, pp. 135-168.

Zhou, M. 1992, Chinatown: the socioeconomic potential of an urban enclave, Temple University Press Philadelphia. 
Zukin, S. 1995, The cultures of cities, Blackwell, Oxford.

Zukin, S. 1998, 'Urban lifestyles: Diversity and standardization in spaces of consumption’, Urban Studies, vol. 35, nos.5-6, pp. 825-839. 
Table 2 Chinatown sample

\begin{tabular}{|c|c|c|c|}
\hline ID & P Type & Gender & Country of Birth \\
\hline $\begin{array}{l}\text { CT.P.1a / CT.P.1b } \\
\end{array}$ & O-M Chinese Restaurant & $\begin{array}{lll}\text { Male } & \\
\end{array}$ & China \\
\hline CT.P.2a / CT.P.2b & O-M Chinese Premium Gift Shop & Male & China \\
\hline CT.P.За / CT.P.Зb & $\begin{array}{l}\text { O-M China-Oriented Travel Agency } \\
\end{array}$ & Male & China \\
\hline CT.P.4a / CT.P.4b & $\mathrm{O}-\mathrm{M}$ Chinese Hairdresser & $\begin{array}{c}\text { Female } \\
\text { Fen }\end{array}$ & China \\
\hline CT.P.5a / CT.P.5b & O-M Chinese Supermarket & Male & China \\
\hline ID & CIM Type & Gender & Country of Birth \\
\hline CT.CIM.1a / CT.CIM.1b & Chinese Ethnic Media Representative & Male & Hong Kong \\
\hline CT.CIM.2a / CT.CIM.2b & State Tourism Body Representative & Female & Australia \\
\hline CT.CIM.3a/CT.CIM.3b & Public CT Promoter & Male & China \\
\hline CT.CIM.4a / CT.CIM.4b & Local Council Representative & Female & Australia \\
\hline CT.CIM.5a / CT.CIM.5b & Chinese Community Group Representativ & Female & China \\
\hline
\end{tabular}

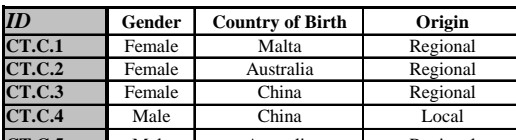

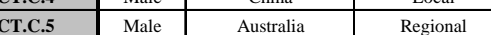

\begin{tabular}{l|c|c|c|} 
CT.C.5 & Male & Australia & Regional \\
\hline CT.C.6 & Female & New Zealand & International \\
\hline CTC 7 & Female & Conada & International \\
\hline CTC.C8 & &
\end{tabular}

\begin{tabular}{l|c|c|c|}
\hline CT.C.8 & Male & Indonesia & Local \\
\hline CT.C. & Male & China & Regional \\
\hline
\end{tabular}

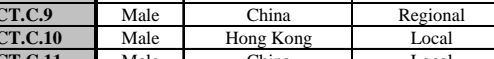

\begin{tabular}{l|c|c|c|}
\hline CT.C.11 & Male & China & Local \\
\hline CT.C.12 & Female & Hong Kong & Local \\
\hline CT.C.13 & Male & Australia & Regional \\
\hline
\end{tabular}

\begin{tabular}{l|c|c|}
\hline CT.C.14 & Male & Indonesia \\
\hline CT. 15 & Fomale & Sri Lanka \\
\hline CT.C.1.
\end{tabular}

CT.C.15

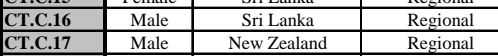

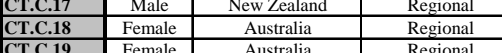

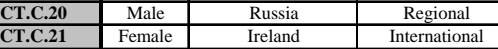

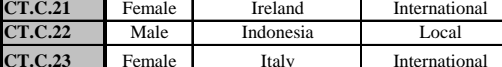

\begin{tabular}{|l|c|c|c|}
\hline CT.C.23 & Female & Italy & International \\
\hline CT.C.24 & Female & Switzerland & Regional \\
\hline C.C.25 & &
\end{tabular}

\begin{tabular}{|c|c|c|c}
\hline CT.C.25 & Female & Australia & National \\
\hline CT.C.26 & . & & \\
\hline
\end{tabular}

\begin{tabular}{|l|c|c|c|}
\hline CT.C.26 & Male & Canada & International \\
\hline CT.C.27 & Male & Ireland & International \\
\hline CT.C.28 & Female & USA & International \\
\hline
\end{tabular}

\begin{tabular}{|c|c|c|c|}
\hline CT.C.C.29 & Male & Australia & Regional \\
\hline CT. & M. & S. \\
\hline
\end{tabular}

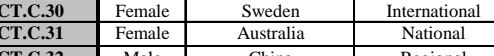

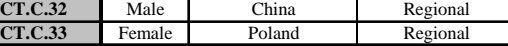

\begin{tabular}{|l|c|c|c|}
\hline C.C.C.33 & Female & Poland & Regional \\
\hline CT.C.34 & Male & Taiwan & Regional \\
\hline CT.C.35 & Tal & & \\
\hline
\end{tabular}

\begin{tabular}{l|c|c|c|}
\hline CT.C.35 & Female & Italy & Inernational \\
\hline CT.C36 & Female & Hong Kong & Regional \\
\hline
\end{tabular}

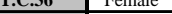

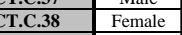

Australia $\quad$ Regional

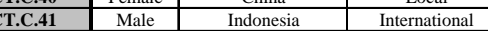

\begin{tabular}{|l|c|c|c|}
\hline CT.C.42 & Male & Australia & Regional \\
\hline CT.C.43 & Male & China & Regional \\
\hline CT.C.44 & Female & China & Local \\
\hline C.C.4 & &
\end{tabular}

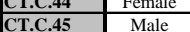

\begin{tabular}{l|c|c|c|}
\hline CT.C.46 & Female & Australia & Local \\
\hline Custralia & Regional \\
\hline
\end{tabular}

\begin{tabular}{l|c|c|c|}
\hline CT.C.47 & Male & Portugal & Regional \\
\hline
\end{tabular}

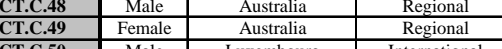

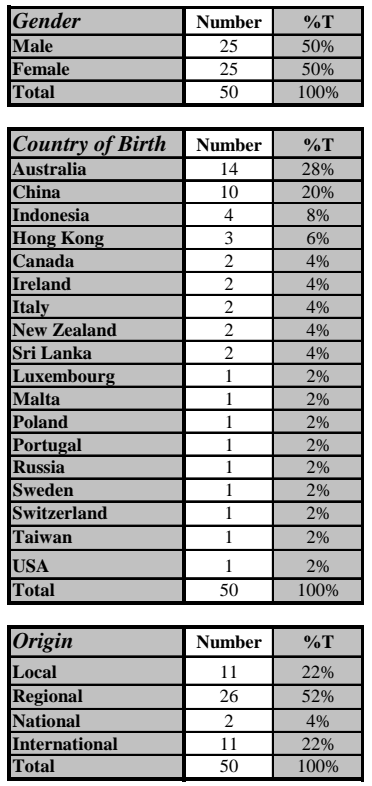


Table 3 Little Italy sample

\begin{tabular}{|l|c|c|c|}
\hline ID & P Type & Gender & Country of Birth \\
\hline LI.P.1a / LI.P.1b & O-M Italian Restaurant & Male & Italy \\
\hline LI.P.2a / LII.P.2b & O-M Italian Café & Male & Italy \\
\hline LII.P.3a /IIP.3b & OM Italian Café & Male & Italy \\
\hline LI.P.4a / LI.P.4b & O-M Italy-Oriented Travel Agency & Male & Italy \\
\hline LI.P.5a / LI.P.5b & O-M Italian Bar & Male & Italy \\
\hline
\end{tabular}

CIM Type

\begin{tabular}{|c|c|c|c|}
\hline$I D$ & CIM Type & Gender & Country of Birth \\
\hline LI.CIM.1a / LI.CIM.1b & $\begin{array}{l}\text { Italian Ethnic Media Representative } \\
\end{array}$ & Male & Italy \\
\hline LI.CIM.2a / LI.CIM.2b & Italian Welfare Association Representative & Male & Australia \\
\hline LI.CIM.3a / LI.CIM.3b & Local Retail O/E Center Representative & $\begin{array}{l}\text { Male } \\
\end{array}$ & $\begin{array}{l}\text { Australia } \\
\end{array}$ \\
\hline LI.CIM.4a / LI.CIM.4b & $\begin{array}{l}\text { Local O/E Association Representative } \\
\end{array}$ & 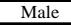 & $\begin{array}{l}\text { Australia } \\
\end{array}$ \\
\hline LI.CIM.5a / LI.CIM.5b & Local Council Representative & $\begin{array}{l}\text { Female } \\
\end{array}$ & $\begin{array}{l}\text { Australia } \\
\end{array}$ \\
\hline
\end{tabular}

I.CIM.5a / LI.CIM.5b Local Council Representative Femal

Note: Both interviews with the 'Australian male 'Italian Welfare Association Representataive"
(ID. LI.CIM.2a/LI.CIM.2b) saw an associate of the latter in attendance, also. The primary researcher's

(ID. LI.CIM.2afLLCIM.2b) saw an associate of the latter in attendance, also. The primary
interaction with this additional individual was very limited in each of the two interviews.

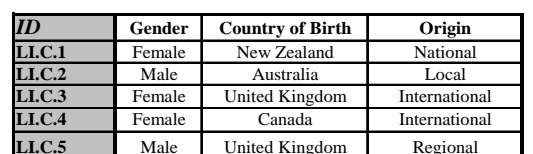

\begin{tabular}{|l|c|c|c|}
\hline LI.C.5 & Male & United Kingdom & Regional \\
\hline L.C. & Male & Australia & Logal \\
\hline
\end{tabular}

\begin{tabular}{|l|c|c|c|}
\hline LI.C.7 & Male & Australia & Regional \\
\hline L.C.8 & Male & Malaysia & Local \\
\hline LI.C.9 & Male & Italy & International \\
\hline U.C.10 & Ienale & Indonesia & Local \\
\hline
\end{tabular}

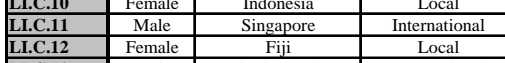

LI.C.14

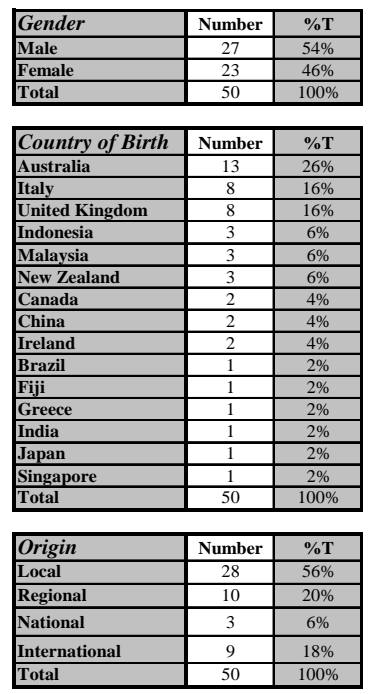


Table 4 Vietnamatta sample

\begin{tabular}{|c|c|c|c|}
\hline ID & \begin{tabular}{|l} 
P Type \\
\end{tabular} & Gender & Country of Birth \\
\hline V.P.1a/V.P.1b & O-M Vietnamese Restaurant & Male & Vietnam \\
\hline V.P.2a / V.P.2b & O-M Vietnamese Restaurant & & Vietnam \\
\hline V.P.3a/ / V.P.3b & O-M Vietnam-Oriented Travel Agency & Female & Vietnam \\
\hline V.P.4a/ / V.P.4b & O-M Vietnam-Oriented Travel Agency & Male & Vietnam \\
\hline V.P.5a/ / V.P.5b & O-M Vietnamese Supermarket & Male & Vietnam \\
\hline ID & CIM Type & Gender & Country of Birth \\
\hline V.CIM.1a / V.CIM.1b & Private V Promoter & Female & India \\
\hline \begin{tabular}{|l} 
V.CIM.2a / V.CIM.2b \\
V.C.
\end{tabular} & Vietnamese Ethnic Media Representative & Male & $\frac{\text { Mietram }}{\text { Vietnam }}$ \\
\hline $\begin{array}{l}\text { V.CIM.3a / V.CIM.3b } \\
\text { V.C. }\end{array}$ & Asian Community Group Representative & Male & China \\
\hline V.CIM.4a / V.CIM.4b & Local O/E Association Representative & Male & Australia \\
\hline V.CIM.5a / V.CIM.5b & Local Council Representative & Male & Vietnam \\
\hline
\end{tabular}
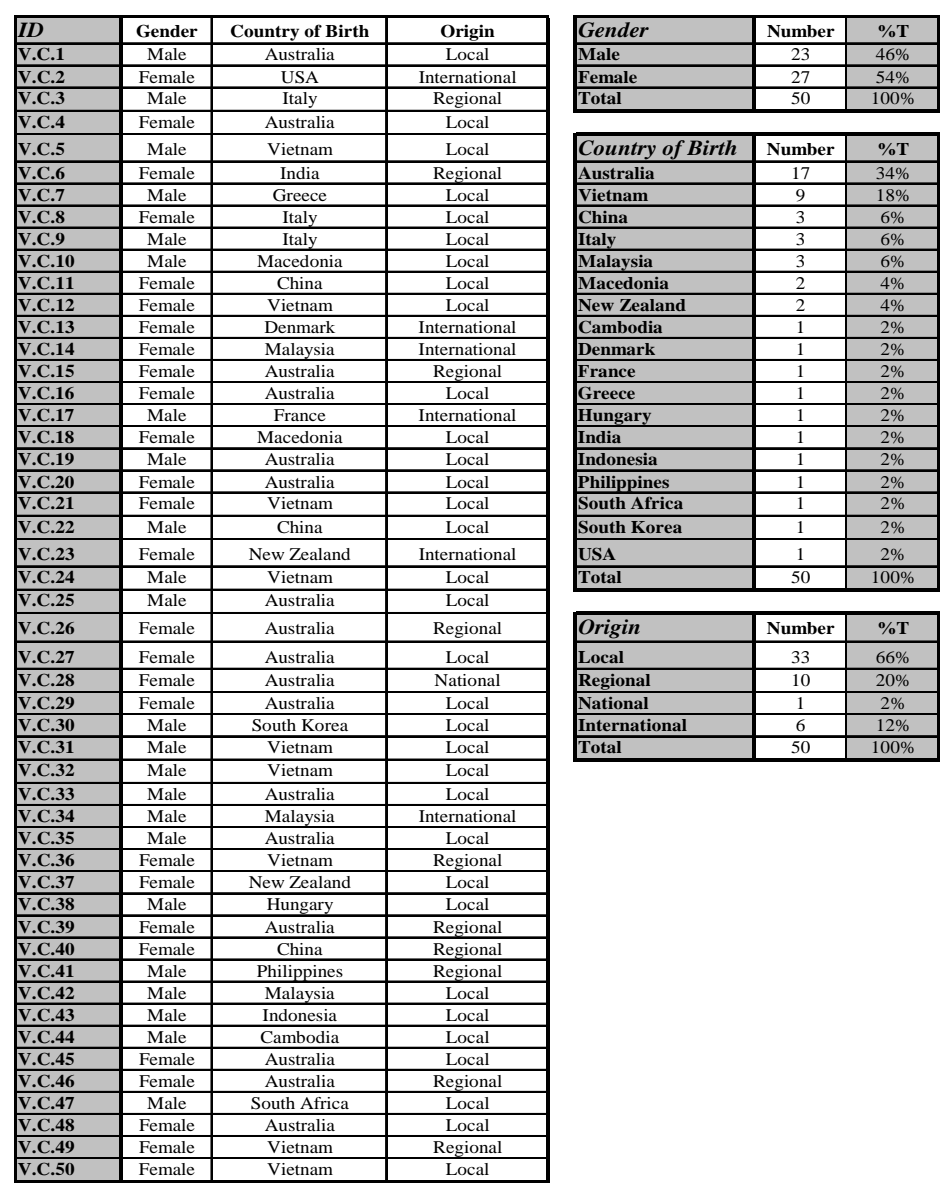
Table 5 Little Turkey sample

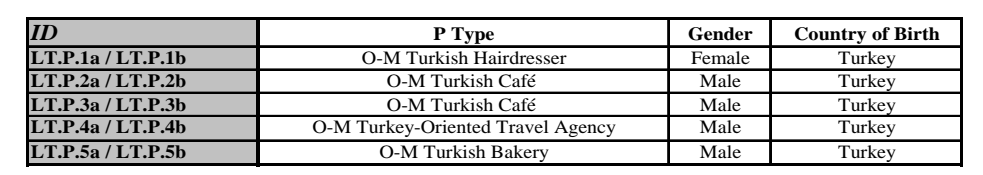

\begin{tabular}{|l|c|c|c|}
\hline ID & CIM Type & Gender & Country of Birth \\
\hline LT.CIM.1a/LT.CIM.1b & Local Council Representative & Female & China \\
\hline LT.CIM.2a/LT.CIM.2b & Turkish Community Group Representative & Male & Turkey \\
\hline LT.CIM.3a/LT.CIM.3b & Turkish O/E Association Representative & Male & Turkey \\
\hline LT.CIM.4a/LT.CIM.4b & Turkish Ethnic Media Representative & Male & Tukkey \\
\hline LT.CIM.5a/LT.CIM.5b & Immigrant O/E Assistance Group Representative & Male & Australia \\
\hline
\end{tabular}

Note: Both interviews with the "Turkish male "Turkish Ethnic Media Representative" (ID. LT.CIM.4a/LT.CIM.4b)

saw an associate of the latter in attendance, also. The primary researcher's interaction with this

additional individual was very limited in each of the two interviews.
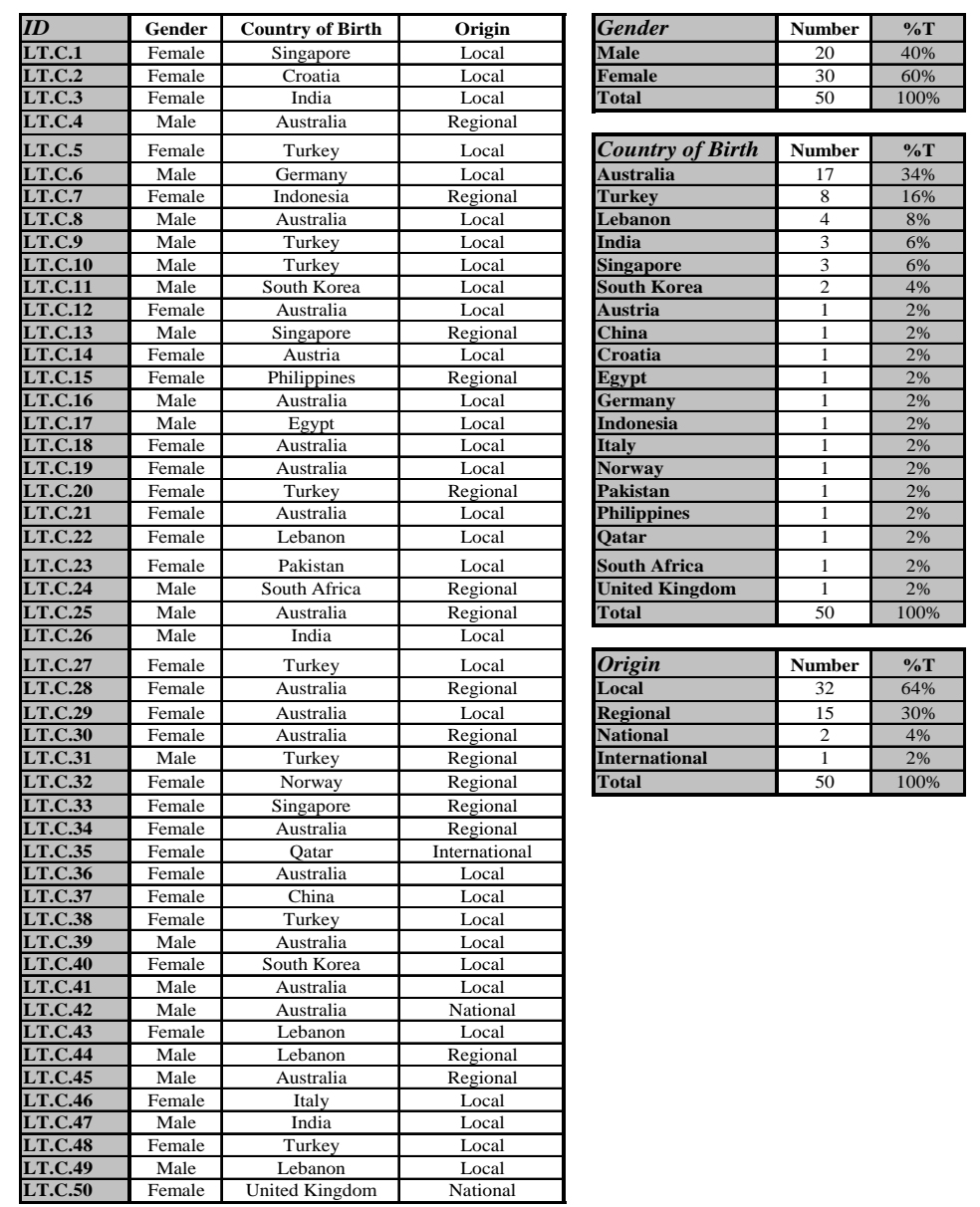